Middle East Journal of Science

Research Article

\title{
ANALYSIS OF OPINIONS AND EXPECTATIONS OF FARMERS ON AGRICULTURAL LAND MARKET: A CASE STUDY FOR TURKEY
}

\author{
Cansu Başaran Caner ${ }^{1 *}$ (iD) Sait Engindeniz ${ }^{2}$ (iD) Zhansaya Bolatova ${ }^{3}$ (iD)
}

${ }^{1}$ Ege University, Faculty of Agriculture, Department of Agricultural Economics, Izmir, Turkey

${ }^{2}$ Ege University, Faculty of Agriculture, Department of Agricultural Economics, Izmir, Turkey

${ }^{3}$ Ege University, Faculty of Agriculture, Department of Agricultural Economics, Izmir, Turkey

"Corresponding author; basarancansu@gmail.com

\begin{abstract}
Due to the ecological and economic crises experienced in recent years, farmers can migrate from rural areas and the sales of agricultural lands can increase. Measures should be taken to keep farmers in rural areas. The purpose of this study is to determine the opinions and expectations of farmers in Aydin province of Turkey on the agricultural land market. The data of the study were collected from 73 farmers with a survey by using proportional sampling. In the analysis of data, first, the socioeconomic characteristics of the farmers were examined, then the farmer's opinions and expectations on the agricultural land market were revealed. Data was interpreted by calculating the average and percentage. The five-point Likert scale was used in the analysis of opinions and expectations. The average age of the farmers is 54.97, average education period is 7.68 years. The average land size is 7.30 hectares. The most important factors affecting the price of agricultural land are land size, soil structure, fertility, road-transportation status, land registry, and cadastre status and location. The issues that farmers consider the most in land purchasing are government supports, economic conditions, location of the land in the same village, and reasonable land price. However, they state that when they have to sell, they can sell it in cash and they will not be interested in what purpose the purchaser will use.
\end{abstract}

Keywords: agricultural land, land market, land price, land value.

Received: June 01, 2021

Accepted: June 28, 2021

\section{Introduction}

The land is an indispensable natural resource for the continuation of the ecosystem. For this reason, it should be used efficiently and in a balanced way [1]. The land is an indispensable production factor for the industry and urbanization sector as well as for the agricultural sector. This situation necessitates the best distribution of land among various uses [2].

The price and value of the parcel of land in Turkey change under the influence of various factors, local, regional, and country The direction of the change in land prices and values differ depending on many factors and prices are generally not stable in the land market [3].On the other hand, agricultural land sales are increasing due to the fact that the rent generated in the area in urban and industrial use is higher than the agricultural use return, the agricultural lands are not large enough, the input costs increase, the risk and uncertainty factor and the fragmentation of farms. 
Undoubtedly, whatever the purpose is, to reach real land prices or values, it is necessary to analyze the functioning of the existing land market first. In Turkey, because the land is a passion for farmers, and moreover, the workplace and livelihoods, the sale of land in rural areas is not found very often. However, in recent years, the ecological (drought, flood, etc.) and economic problems faced by the farmers have also increased land sales. Potential development trends, especially in the region where the land is located, is the main factor that determines the price in the agricultural land market [4].

Many studies have been conducted on the functioning of the agricultural land market and determining factors affecting the value of agricultural land in Turkey $[5,6,7,8,9,10,11,12,13,14$, $15,16,17]$. However, it is also necessary to conduct researches to determine the opinions and expectations of farmers in terms of the functioning of the agricultural land market in different regions.

Due to the ecological and economic crises experienced in recent years, farmers can migrate from rural areas and the sales of agricultural lands can increase. Measures should be taken to keep farmers in rural areas. The purpose of this study is to determine the opinions and expectations of farmers in Aydin province of Turkey on the agricultural land market.

\section{Material and Methods}

Aydin province, of which $45.07 \%$ of its total area is agricultural land, has significant agricultural potential with its soil, climate, and ecological characteristics. Efeler district is on the fertile agricultural lands irrigated by the Büyük Menderes Plain. Gaining metropolitan status and other regulations put into effect affect the agricultural land markets in Efeler district.

The main material of the study is the data compiled using a questionnaire method from the farmers in Efeler district of Aydin province (Figure 1). According to data for 2018 of the Turkish Statistical Institute, the most densely populated district of Aydın province, with 287,518 people are added to the metropolitan municipality as the new district is the Efeler district [18].

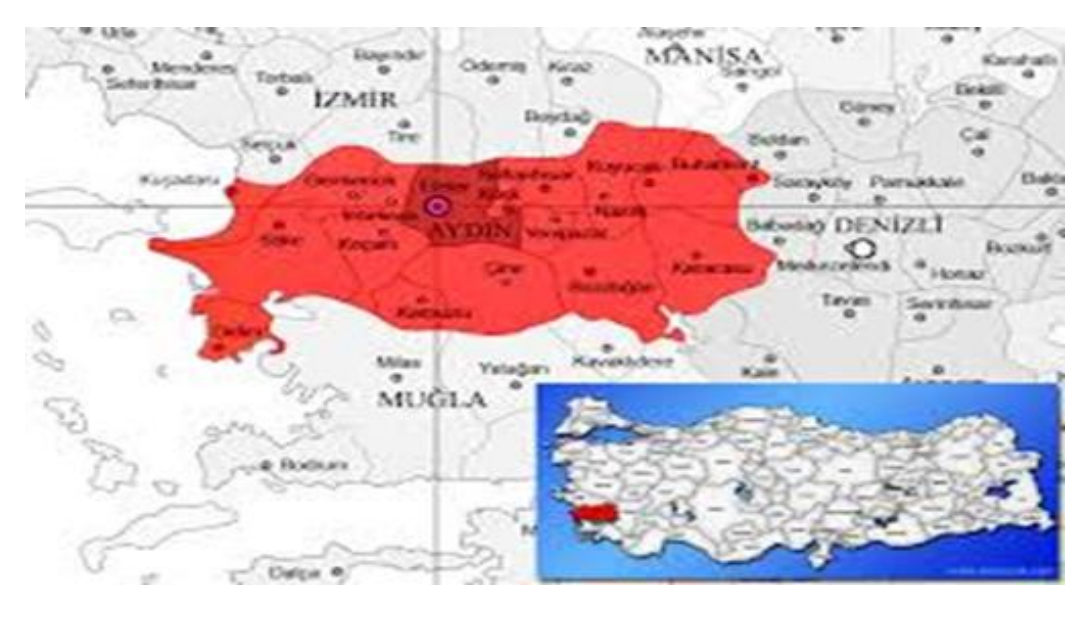

Figure 1. Research area in Turkey

There are 83 neighborhoods in Efeler district and 61 villages and towns have gained neighborhood status with the law numbered $6360.10 \%$ of 61 neighborhoods outside the urban area were included in the study, and six of the neighborhoods within $10 \mathrm{~km}$ of the city center were selected as purposeful. Accordingly, the neighborhoods of Çeştepe, Işıklı, Kadıköy, Kuyulu, Şevketiye and Tepecik were 
included in the study. According to the information obtained from the Efeler District Directorate of the Ministry of Agriculture and Forestry, there are 298 farmers registered in the Farmer Registration System in the settlements included in the study. It was decided to include some of the farmers in the scope of the research by sampling method. For this purpose, the following proportional sample size formula was used [19].

$$
n=\frac{N p(1-p)}{(N-1) \sigma_{p x}^{2}+p(1-p)}
$$

In the formula;

$\mathrm{n}=$ Sample size

$\mathrm{N}=$ Total number of farmers

$\mathrm{p}=$ Proportion of farmers producing on irrigable land (taken 0.5 to reach maximum sample size) $\sigma_{p x}^{2}=$ Variance.

In the study, calculations were made based on $95 \%$ confidence interval and $10 \%$ margin of error, and the sample size was determined as 73 . In determining the number of farmers to be included in each neighborhood, the shares of the neighborhoods in the total number of farmers were taken as a basis. Data were collected from farmers in January 2017.

In this study, in line with the recommendations of the University Ethics Committee, the farmers to be surveyed were informed about the aims of the study, their rights and limitations, their voluntary participation in the study, and the prepared consent form were filled and the questions were answered.

In the analysis of the research data, first, the socio-economic characteristics of the farmers were examined, then the farmer's opinions and expectations on the agricultural land market were revealed. In the research, the data were interpreted by calculating the average and percentage. The five-point Likert scale was used in the analysis of opinions and expectations.

\section{Results and Discussion}

The socio-economic characteristics of the farmers are presented in Table 1. The age of the farmers varies between 24-76 and the average age is 54.97. The period of education varies between 5-16 years and the average period of education is 7.68 years. The average agricultural experience of the farmers is 24.59 years.

The average household size in the farms is 3.33 and $50.45 \%$ of them are men. The average family labor force potential in farms is 1.95 as a unit of the male labor force and 585 as a male labor day. The average land size of the farms is 7.30 hectares. The average number of parcels is 3.42 and the average parcel size is 2.13 hectares. Cotton, wheat, corn, and vetch are mostly produced on farmlands.

Table 1. Socio-economic characteristics of farmers

\begin{tabular}{lr}
\hline Age of farmers & 54.97 \\
Education period of farmers (year) & 7.68 \\
Agricultural experience of farmers (year) & 24.59 \\
Household size (person) & 3.33 \\
Family labor force potential (male work unit) & 1.95 \\
Land size (ha) & 7.30 \\
Equity ratio (\%) & 85.42 \\
Partner ratio in an agricultural cooperative (\%) & 84.93 \\
\hline
\end{tabular}


As the average of the farms, $90.92 \%$ of the total assets are land assets. When analyzed the distribution of assets according to the items; a large share of land assets (83.88\%), followed by tools and machinery (6.91\%) and buildings (4.99\%), respectively. However, $85.42 \%$ of the passive capital is equity capital. 62 of the 73 farmers included in the study are partners in at least one agricultural cooperative.

When the frequency of land sales in the settlements within the scope of the study was examined, $82.19 \%$ of the farmers stated that they were sold once a year, and $17.81 \%$ stated that they were sold twice a year. It was determined that $98.63 \%$ of the farmers did not purchase land recently. The farmers, who stated that they were purchasing land, bought it from their neighbor in the village.

In the research area, 12 irrigable agricultural lands have been sold in the last year. Three of the lands are located in Iş1klı, two in Tepecik, two in Çeştepe, two in Kuyulu, two in Şevketiye and one in Kadiköy. The size of the lands varies between 0,3 ha-3,3 ha. The average land size was determined as 1,5 ha. It was determined that cotton-wheat, cotton-corn, and cotton-silage corn rotations were applied in the fields. The sale price of land per hectare varies between 126,580 US\$-455,690 US\$. The average selling price was calculated as $216,540 \mathrm{US} \$ / \mathrm{ha}$.

When the opinions of the farmers about the change in the value of agricultural lands in the coming years are examined, it was determined that $68.5 \%$ of them think that the value of the agricultural lands will increase rapidly in the coming years. $95.89 \%$ of the farmers stated that the land prices increased after their villages became neighborhoods. According to the farmers in the research region, the average real value was determined to be $225,807.28$ US $\$$ /ha for irrigated field lands and $214,127.59$ US\$/ha for dry field lands, respectively.

When asked to farmers which of the factors affecting the land price were effective, the answers were obtained in Table 2. According to the farmers, the most important factors affecting the price of agricultural land are land size, soil structure, fertility, road-transportation status, land registry, and cadastre status and location. In addition, irrigation conditions, shape, and the crops grown on land were determined as other important factors.

Table 2. Level of importance that farmers attach to factors affecting the agricultural land price

\begin{tabular}{lcc}
\hline Factors & Mean* & Standard deviation \\
\hline Land size & 4.50 & 0.50 \\
Fertility & 4.44 & 0.60 \\
Soil structure & 4.36 & 0.68 \\
Road-transportation status & 4.13 & 1.05 \\
Land registry and cadastre status & 4.10 & 1.12 \\
Location & 3.89 & 1.08 \\
Irrigation conditions & 3.81 & 1.17 \\
Shape & 3.72 & 1.29 \\
Crops grown on land & 3.39 & 1.49 \\
Providing ease of payment to the purchaser & 2.38 & 1.50 \\
Purchasers' attitudes and behaviors & 2.26 & 1.45 \\
Mediation by close relatives and/or friends & 2.24 & 1.45 \\
Sellers be in debt and compulsorily selling & 2.10 & 1.33 \\
The kinship of purchasers and sellers & 2.08 & 1.36 \\
\hline
\end{tabular}

*1: Not important, 2: Slightly important, 3: Moderately important, 4: Important, 5: Very important 
The factors that have the most impact on the price of agricultural land have also been determined in previous studies. These factors were determined to be land size, fertility, road, and transport conditions [20], irrigation conditions, soil structure and fertility, road and transport conditions, location and land size [21], land registry and cadastre status, land size, irrigation status, road-transportation status and fertility [22] respectively.

In the research, different conditions were presented to the farmers in order to put their opinions and expectations on land purchasing and the level of their participation was asked. The answers of farmers are presented in Table 3. The issues that farmers consider the most in land purchasing are government supports, economic conditions, location of the land in the same village, and reasonable land price. In addition, the fertility status of the land, increases in product prices, labor supply in the region, decrease in input costs, increase in product prices, convenience in payment terms, and suitable credit opportunities are other important issues.

Table 3. Opinions and expectations of farmers on land purchase

\begin{tabular}{llc}
\hline Opinions/Expectations & Mean* & Standard deviation \\
\hline If government support increases, I can purchase land. & 4.51 & 0.73 \\
\hline If my economic situation is good, I can purchase land. & 4.49 & 0.71 \\
\hline If I purchase land, I will buy the land in the village. & 4.47 & 0.65 \\
\hline If I find land with reasonable prices, I can purchase it. & 4.44 & 0.82 \\
\hline If I find fertile land, I will purchase it. & 4.29 & 1.03 \\
\hline If the payment terms are suitable, I can purchase land. & 4.23 & 1.14 \\
\hline If crop prices rise, I can purchase land to expand my land. & 4.21 & 1.05 \\
\hline I can purchase land to grow my farm. & 4.19 & 1.21 \\
\hline I can purchase land if there is a suitable credit opportunity. & 4.16 & 1.16 \\
\hline If I purchase land, I will use it for agricultural purposes. & 4.01 & 1.23 \\
\hline If the labor supply is sufficient in the region, I can purchase land. & 3.96 & 1.39 \\
\hline If I find some land on the road, I can purchase it. & 3.90 & 1.45 \\
\hline If input prices decrease, I can purchase land. & 3.89 & 1.51 \\
\hline I can expand my land to increase the use of agricultural mechanization. & 3.33 & 1.65 \\
\hline If I find land close to the market, I can purchase it. & 3.27 & 1.58 \\
\hline I purchase land thinking that my prestige in the village will increase. & 3.14 & 1.66 \\
\hline It is important for me which products are grown on the land before I buy. & 3.16 & 1.45 \\
\hline I can purchase land to rent. & 2.21 & 1.43 \\
\hline Purchasing land may disrupt my farm integrity. & 1.45 & 1.01 \\
\hline I do not intend to purchase land regardless of the conditions, & \\
\hline
\end{tabular}

*1: Strongly disagree, 2: Disagree, 3. Undecided, 4: Agree, 5: Strongly agree

Similar results have been obtained in many previous studies in Turkey. The issues that farmers consider the most in land purchasing; it was determined to be economic conditions, reasonable land price, payment terms and fertility of the land [20], economic conditions, reasonable land price, sufficient labor opportunities, and the proximity of the land to the road [21], economic conditions, reasonable land price and location of the land in the same village [22] respectively. 
In the research, different conditions were presented to the farmers in order to put their opinions and expectations on land selling, and the level of their participation was asked. The answers of farmers are presented in Table 4. When the issues that the farmers take into consideration in selling land are examined, it is seen that the majority of the farmers do not intend to sell the land regardless of the conditions. Farmers believe that their farms will shrink if they sell their land. For this reason, they prefer to lease their unprocessed land rather than sell it. However, they state that when they have to sell, they can sell it in cash and they will not be interested in what purpose the purchaser will use.

Table 4. Opinions and expectations of farmers on land sell

\begin{tabular}{lcc}
\hline Opinions/Expectations & Mean* & Standard deviation \\
\hline I do not sell land regardless of the conditions. & 3.95 & 1.39 \\
If I sell my land, I will sell it in cash. & 3.90 & 1.44 \\
If I sell some of my land, my farm shrinks. & 3.84 & 1.30 \\
The intended use of the person who will buy my land is not important to me. & 3.79 & 1.50 \\
It would be better if I let the land I didn't cultivate for rent rather than sell it. & 3.59 & 1.47 \\
Selling some of my lands can make it difficult for me to use credit. & 3.36 & 1.49 \\
If I have financial difficulties, I can sell some of my lands. & 3.01 & 1.53 \\
If I sell some of my lands, I will sell it to someone in the village. & 2.55 & 1.52 \\
I do not sell land thinking that my reputation in the village will decrease. & 2.48 & 1.70 \\
I can sell my inefficient lands. & 2.22 & 1.62 \\
If there is a good price, I can sell land. & 1.93 & 1.39 \\
I can sell my non-irrigated lands & 1.77 & 1.14 \\
If I leave the agricultural sector, I will sell my land. & 1.66 & 1.17 \\
Selling land that I have not cultivated can provide economic benefits. & 1.60 & 0.97 \\
I can sell land if I migrate to the city. & 1.56 & 1.07 \\
If I cannot find the required labor force, I can sell my land. & 1.53 & 0.84 \\
I can sell land if input prices increase. & 1.38 & 0.68 \\
If I have difficulties with tools and equipment to cultivate the land, I can sell it. & 1.37 & 0.77 \\
I can sell land if there is an ecological crisis (drought, flood, frost, etc.) & 1.34 & 0.65 \\
\hline
\end{tabular}

*1: Strongly disagree, 2: Disagree, 3. Undecided, 4: Agree, 5: Strongly agree

Similar results have been obtained in many previous studies in Turkey. The issues that farmers consider the most in land selling; it was determined to be cash payment and the purchaser is from the village [20], economic conditions and cash payment [21], cash payment and uncultivated land [22], respectively.

In the study, the farmers evaluate the spreading of the city center towards the villages as negative $(75.34 \%)$ in terms of land use. Farmers stated that the most common non-agricultural use of agricultural lands in the region is for residential construction $(89.87 \%)$, then for industry $(10.13 \%)$. On the other hand, $58.90 \%$ of the farmers stated that they would consider selling if their lands were parceled by the municipality, while $40.10 \%$ would not sell. 


\section{Conclusion}

Today, information about land prices and values; There is a need for transactions such as expropriation, taxation, easement right establishment, crediting, purchase-sale, inheritance sharing, loss and loss determination. In addition, land prices and values are important data used in the realization of public and private sector investments, in resolving disputes regarding lands, and in the preparation of scientific research.

According to the results of the study, farmers tend to purchase and sell land for different reasons. The most important reasons for purchasing land; increased government supports, economic conditions, availability of land in the village, favorable land price, fertility of the land, favorable payment terms, desire to expand the farmland, and favorable credit conditions. Farmers state that if they purchase land, they will use it for agricultural purposes. In case they sell land, they give importance to the realization of the sale in cash. In case they sell land, they give importance to the realization of the sale in cash. However, most of the farmers do not intend to sell land regardless of the conditions.

In the light of the results of the study, it can be said that the economic conditions in the region are more decisive for the purchase and sale of land. In addition, non-agricultural use of land, urbanization, and the fact that the lands are not very fragmented and insufficient size are also effective in purchasing and selling these lands. It is important to create a functioning agricultural land market in order to ensure the sustainability of agricultural land. The legal and institutional arrangements needed to ensure the purchase and sale of agricultural land, the regulation of credit, partnership, tenancy affairs in this regard, and the orientation of the lands to production should be realized.

In the study, most of the farmers stated that the most common use of agricultural lands other than agriculture is housing construction and that they can sell their lands after urban fringing. In Turkey, urbanization policies and other regulations should not adversely affect the agricultural structure and should be arranged in a way that does not exclude farmers from agriculture. Only in this way will the optimum balance between natural resources and urban uses be achieved.

Conflict of interest: The authors have declared no conflict of interest.

The compliance to Research and Publication Ethics: This work was carried out by obeying research and ethics rules.

Authors' Contributions: All authors mentioned in the paper contributed equally to the research. All authors read and approved the final manuscript

\section{References}

[1] Sezgin, D., The Effect of Urban Fringing on the Misuse of Fertile Agricultural Soils: The Case of Ankara, Master Thesis, Institute of Science and Technology of Gazi University, Ankara, 2010

[2] Paksoy, M., Direk, M., "Use of Agricultural Lands for Non-Agricultural Purposes" Journal of Ecology, 13, 17-20, 1994

[3] Demirci, R., Tanrıvermiş, H., Aliefendioğlu, Y., "Land Management and Market in Turkey: Basics, Legal and Institutional Arrangements, Problems and Effects on Valuation Studies" Journal of Third Sector Cooperative, 142, 38-63, 2008 
[4] Rehber, E., Agricultural Valuation and Expertise, Publication of Ekin, Bursa, 2008

[5] Bedestenci, H.C., Vuruş, H., “The Farmland Sales in Ceyhan Plains in Turkey”, KSU Journal of Science and Engineering, 3, 154-162, 2000

[6] Vural, H., "A Quantitative Approach to the Valuation of Land in Turkey: The Case of Bursa Karacabey Plain” Journal of Agricultural Faculty of Uludağ University, 21, 13-20, 2007

[7] Hurma, H., Analysis of the Effects of Environmental Quality on Agricultural Land Value: The Case of Trakya. Doctorate Thesis, Institute of Science and Technology of Namık Kemal University, Tekirdağ, 2007

[8] Vural, H., Fidan, H., "Land Marketing and Hedonic Price Model in Turkish Markets: Case Study of Karacabey District of Bursa Province" African Journal of Agri-cultural Research 4, 71-75, 2019

[9] Aliefendioğlu, Y., The Impacts of Use and Conservation Status of Real Estates in Conservation Areas from the Viewpoint of Real Estate Markets and Values in Turkey: The Case of Muğla Province. Doctorate Thesis, Institute of Science and Technology of Ankara University, Ankara, 2011

[10] Karakayac1, Z., 2011. The Use of Geographical Information Systems in the Valuation of Agricultural Lands: The Case of Çumra District of Konya Province, Doctorate Thesis, Institute of Social Sciences of Selçuk University, Konya, 302 p.

[11] Öztürk Coşar, G., Engindeniz, S., "Hedonic Analysis of Agricultural Land Values: The Case of Menemen District of Izmir" Journal of Agriculture Faculty of Ege University, 50, 241-250, 2013

[12] Karakayac1, Z., "Using of Analytic Hierarchy Process on Evaluating the Affecting Factors in the Value of Farmlands" Bulgarian Journal of Agricultural Science, 21, 719-724, 2015

[13] Başer, U., K1lıç, O., "Determination of Factors Affecting Land Price: Ladik District of Samsun Province", XII. National Agricultural Economics Congress, Isparta, Turkey, 2016, pp:273-280

[14] Öztürk, G., Engindeniz, S., Bayraktar, O.V., “Analysis of Factors Effect on Irrigated Agricultural Land Values in Izmir" Selçuk Journal of Agriculture and Food Sciences, 31, 75-87, 2017

[15] Çınar, G., Can, A., Özcan, H., Aslan, F., "The Prediction of the Factors that Have Affected Agricultural Value in Aydin by the Hedonic Pricing Model", Ahtamara I. International Multidisciplinary Studies Congress, Van, Turkey, 2018, pp. 58-67

[16] Aydın Can, B., Engindeniz, S., "Farmers' Opinions and Expectations about Agricultural Land Expropriations: A Case Study of Kocaeli Kandıra Food Specialized Organized Industrial Zone" Turkish Journal Agricultural Economics, 24, 77-84, 2018.

[17] Başer, U., Kılıç, O., Abac1, H.S., "Determining Direct and Indirect Effects of the Factors Influencing Land Price by Path Analysis: A Case Study of Ladik District-Samsun”, Turkish Journal of Agricultural Research, 6, 50-56, 2019 
Middle East Journal of Science (2021) 7(1): 80-88 https://doi.org/10.51477/mejs.945047

[18] TurkStat. (2019). "Population and Labor Statistics, https://www.tuik.gov.tr, Access: 25 January 2019.

[19] Newbold, P., Statistics for Business and Economics, Prentice-Hall, New Jersey, 1995

[20] Öztürk Coşar, G., A Study on Determining the Factors Affecting the Value of Irrigated Field Lands in Menemen District, Master Thesis, Institute of Science and Technology of Ege University, Izmir, 2013

[21] Karaca, D., İbraimi, S., Engindeniz, S., Akyüz, Y. Çınar, G., “Analysis of Factor Affecting Farmers' Decisions on Purchase and Sale of Land: A Case Study for Kemalpaşa District of Izmir" Journal of Agriculture Faculty of Ege University, 53, 481-489, 2016

[22] Subay, K., Engindeniz, S. and Örük, G., (2019). "Opinions and Tendencies on Land Selling and Purchasing of the Farmers in Bayındır District of Izmir Province", International Agricultural Congress of Mus Plain, Muş, Turkey, 2019 